\title{
Mangrove Forests Evolution and Threats in the Caribbean Sea of Colombia
}

\author{
Diego Andrés Villate Daza ${ }^{1}$, Hernando Sánchez Moreno ${ }^{2}$, Luana Portz ${ }^{3, * \mathbb{C}}$, \\ Rogério Portantiolo Manzolli ${ }^{3}$ (D), Hernando José Bolívar-Anillo ${ }^{2, *(\mathbb{D})}$ and Giorgio Anfuso 4 (D) \\ 1 Grupo de Investigaciones Marino Costeras GIMAC, Escuela Naval de Suboficiales ARC, Barranquilla 080002, \\ Colombia; godievi@gmail.com \\ 2 Laboratorio de Investigación en Microbiología, Universidad Simón Bolívar, Barranquilla 080002, Colombia; \\ hsanchez13@unisimonbolivar.edu.co \\ 3 Department of Civil and Environmental, Universidad De La Costa, Barranquilla 080002, Colombia; \\ rportant1@cuc.edu.co \\ 4 Departamento de Ciencias de la Tierra, Facultad de Ciencias del Mar y Ambientales, Universidad de Cádiz, \\ 11510 Puerto Real (Cádiz), Spain; giorgio.anfuso@uca.es \\ * Correspondence: lportz1@cuc.edu.co (L.P.); hbolivar1@unisimonbolivar.edu.co (H.J.B.-A.)
}

Received: 11 March 2020; Accepted: 11 April 2020; Published: 15 April 2020

check for updates

\begin{abstract}
Colombia has approximately 379,954 hectares of mangrove forests distributed along the Pacific Ocean and the Caribbean Sea coasts. Such forests are experiencing the highest annual rate of loss recorded in South America and, in the last three decades, approximately 40,000 hectares have been greatly affected by natural and, especially, human impacts. This study determined, by the use of Landsat multispectral satellite images, the evolution of three mangrove forests located in the Colombian Caribbean Sea: Malloquín, Totumo, and La Virgen swamps. Mangrove forest at Mallorquín Swamp recorded a loss of 15 ha in the period of 1985-2018, associated with alterations in forest hydrology, illegal logging, urban growth, and coastal erosion. Totumo Swamp lost 301 ha in the period 1985-2018 associated with changes in hydrological conditions, illegal logging, and increased agricultural and livestock uses. La Virgen Swamp presented a loss of 31 ha in the period of 2013-2018 that was linked to the construction of a roadway, alterations of hydrological conditions, illegal logging, and soil urbanization, mainly for tourist purposes. Although Colombian legislation has made efforts to protect mangrove ecosystems, human activities are the main cause of mangrove degradation, and thus it is mandatory for the local population to understand the value of the ecosystem services provided by mangroves.
\end{abstract}

Keywords: mangrove; coastal dynamic; salinization; Rhizophora mangle; Avicennia germinans; Laguncularia racemosa

\section{Introduction}

Mangrove forests are composed of unique plant species, that is, halophilic trees and shrubs that have specific morphological, physiological, and reproductive characteristics that enable them to survive in a critical interface among terrestrial, estuarine, and near-shore marine ecosystems in tropical and subtropical regions around the world. They are considered one of the most productive natural ecosystems on earth because of their relevant ecosystem services and ecological functions, such as being a nesting habitat for fishes, birds, marine mammals, crustaceans, amphibians, and reptiles. They also act as effective nutrient filters, support numerous rural economies, and protect coastal communities from storms and floods by acting as windbreaks and wave barriers, reducing coastal erosion [1-7]. Last but not least, mangrove forests, due to their great biomass (above- and below-ground) and capacity of 
accumulation of sediments, are able to store more carbon (on average $22 \pm 6 \mathrm{Tg}_{\mathrm{gear}}{ }^{-1}$ ) than terrestrial forests, making them one of the most carbon-rich ecosystems in the tropics, with an estimated value of USD 194,000 per hectare per year [8].

Mangrove forests currently occupy less than 14 million hectares, representing $<1 \%$ of the world's coastal areas, of which more than two-thirds are located in 18 countries: Indonesia, Brazil, Australia, Mexico, Nigeria, Malaysia, Myanmar, Bangladesh, Cuba, India, Papua New Guinea, Colombia, Guinea Bissau, Mozambique, Madagascar, the Philippines, Thailand, and Vietnam [1,3]. It is estimated that approximately $35 \%$ of mangrove forests disappeared during the last two decades of the 20th century, mainly due to their direct conversion to different land uses $[1,6,9,10]$ such as aquaculture, agriculture, urbanization, and impacts due to alterations in the hydrology of river basins and changes in fluvial sediment inflow, among others [3,5,7,11,12]. Although the rate of mangrove forest loss has decreased significantly in the last two decades, it is still worrying, with rates of up to $3.1 \%$ per year in some countries - this could lead to a loss of their functionality in less than 100 years. In addition, only $6.9 \%$ of the world mangroves are protected, and hence it is mandatory to establish new areas of protection in an effort to reduce the rate of loss $[1,4,10,13]$. It is estimated that between 0.02 and $0.12 \mathrm{Pg}$ per year of carbon have been released into the atmosphere as a consequence of mangrove degradation, which represents $10 \%$ of the total emissions resulting from deforestation [7]. Therefore, global net loss of mangroves would require the successful rehabilitation of about 100,000 ha per year unless the necessary measures were taken to halt current mangrove losses [14]. Further, mangroves work as a transitional intertidal ecosystem that is particularly vulnerable to the effects of climate change, mainly those linked to rising sea level, surface water warming, warming and changes in the composition of the atmosphere, and changes in rainfall, among others [5,12]. In different regions of Latin America and the Caribbean, climate change is considered to be the main driver of environmental impacts on mangroves [12]. Natural and anthropogenic stressors may interact in an additive or synergistic manner, which could lead to accelerated and massive alterations of these ecosystems [11]. However, mangrove forests are considered as a highly resilient ecosystem that has the capacity to adapt and adjust to changing conditions [6], and hence it can play a fundamental role in the design of climate change adaptation strategies.

Mangrove forests observed in Latin America and the Caribbean represent around $26 \%$ of the total amount recorded at world scale. They cover an area between 3.58 and $4.54 \times 10^{6}$ ha, of which $80 \%$ is found in six countries: Brazil, Mexico, Cuba, Colombia, Venezuela, and Honduras [12]. On the western side of South America, the largest mangrove forest cover is found in the tropical zone of the Colombian Pacific coast and in northern Ecuador [15]. Colombia is characterized as being the only country of South America with coasts in the Pacific Ocean and the Caribbean Sea with an extension of 1200 and $1800 \mathrm{~km}$, respectively. Differences in precipitation and tidal range between both coasts favor the existence of almost continuous strips of mangroves along the Pacific coast, whereas in the Caribbean this ecosystem is closely linked to freshwater sources [16].

Overall, Colombia has a mangrove forest cover of around 379,954 ha, with 292,724 and 87,230 ha respectively located on the Pacific and Caribbean coasts $[15,17,18]$. They show a total amount of eight species: Rhizophora mangle, Rhizophora harrisonii, Rhizophora racemosa, Laguncularia racemosa, Conocarpus erectus, Avicennia germinans, Avicennia harrisoni, Pelliciera rhizophorae, and Mora oleifera.

On the Caribbean coast of Colombia, in the Department of Atlántico (Figure 1), there are currently around 613.3 hectares of mangrove forests located in different municipalities [19] and, along the coast of the Department of Bolivar, they currently occupy a surface of around 7000 hectares [20]. This paper determines the evolution, during the last decades, of the most extended and representative mangrove forests on the Colombian Caribbean coast between Barranquilla and Cartagena de Indias (departments of Atlántico and Bolívar)_Mallorquín, La Virgen, and Totumo mangrove swamps (Figure 1). This study took into consideration both natural changes (due to coastal erosion/accretion, etc.) and those produced by anthropic activities [21], which have influenced the evolution of the aforementioned mangrove forests, in order to design adequate plans for their environmental improvement and sound 
conservation strategies. The present paper investigates their evolution and their human (deforestation, road construction, etc.) and natural impacts (salinity variations, coastal erosion, etc.) on three mangrove forests located at the departments of Atlántico and Bolívar, located in the Caribbean coast of Colombia (Figure 1). Such areas are characterized by five mangrove species that are common along the Colombian Caribbean Sea [21]: Rhizophora mangle, Avicennia germinans, Laguncularia racemosa, Conocarpus erectus, and Pelliciera rhizophorae.

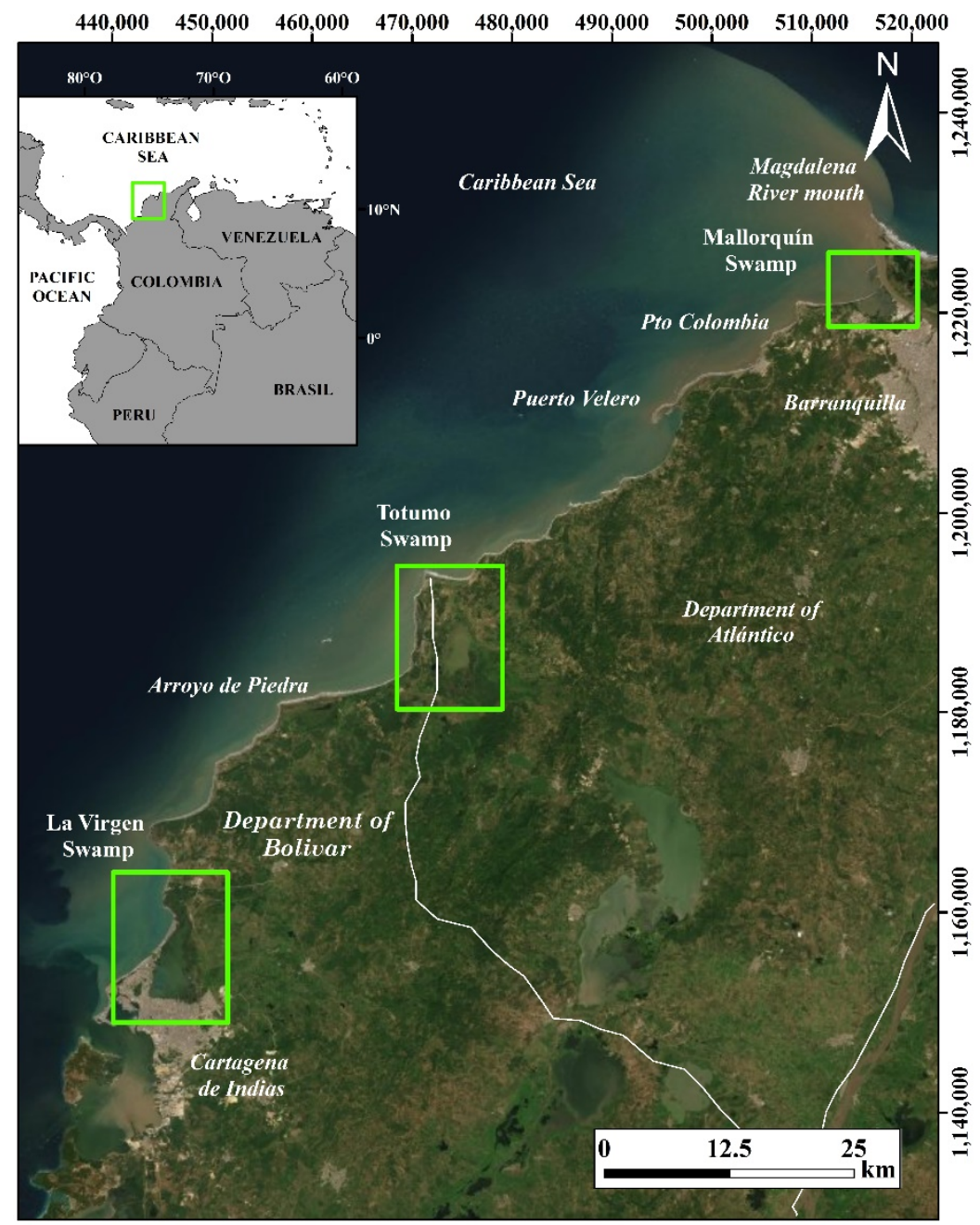

Figure 1. Location map with studied mangrove forests.

\section{Study Area}

The Caribbean coast of Colombia is a tropical environment with seasonal variations in rainfall (Figure 2) from the dry season (December-March) and the transitional seasonal (April-July) to the rainy season (August-November) [22,23]. 


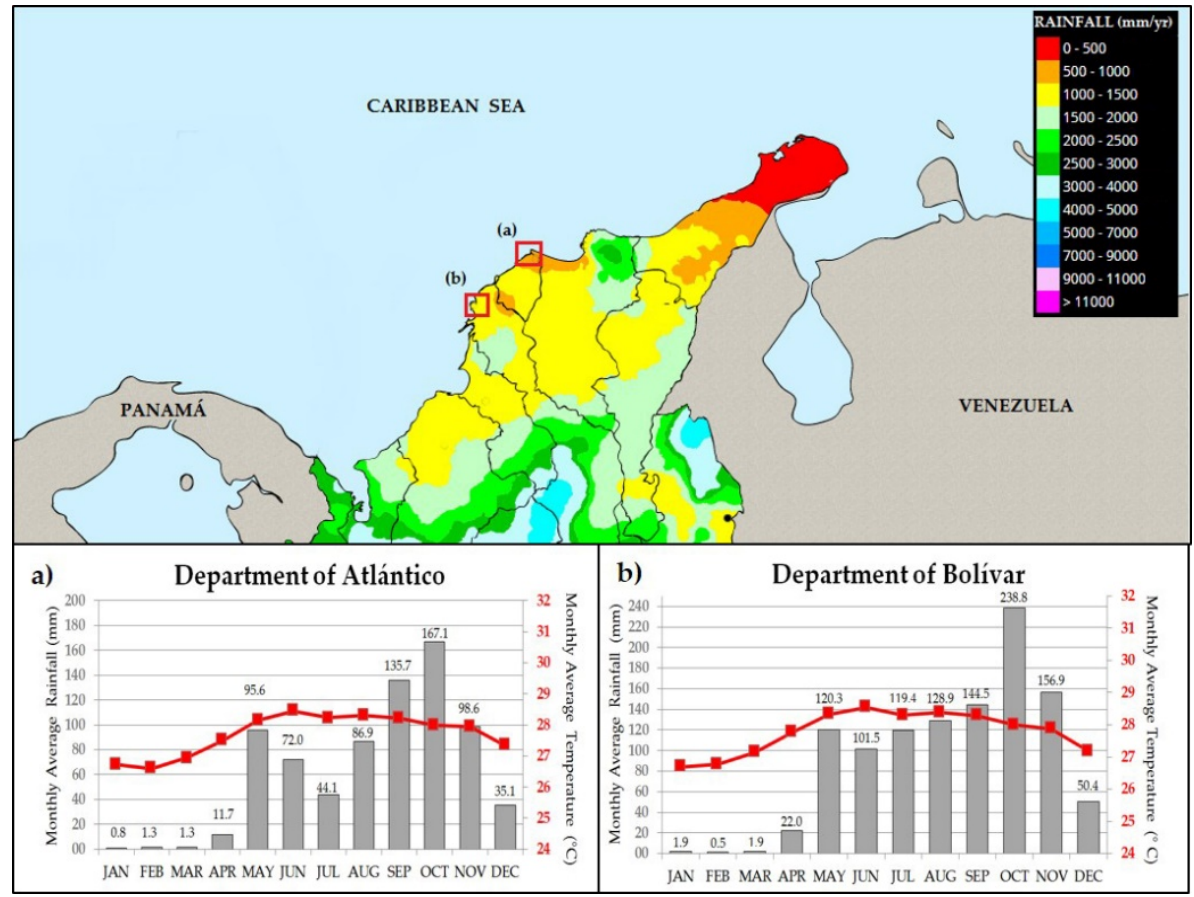

Figure 2. Rainfall and temperature variations at Colombian Caribbean coast (data recorded in the 1980-2010 period- IDEAM [24]): (a) Department of Atlántico; (b) Department of Bolivar.

The main regulator of rain cycles throughout the Colombian territory is the Intertropical Convergence Zone $[25,26]$. This low pressure equatorial system follows the synchronization of the sun [27] and a southern movement (between 27.5 $\mathrm{S}$ and $27.5^{\circ} \mathrm{N}$ ), having the largest amount of solar energy received by the planet [28]. Other oscillations, such as Maiden and Julian, as well as the variability associated with the El Niño and La Niña phenomena (Southern Oscillation-ENSO) in the Pacific, contribute especially to the intensity of the precipitation anomalies on the Colombian Caribbean coast [26]. Tide has mixed semi-diurnal periodicity and microtidal variability, with maximum values of $60 \mathrm{~cm}$ [22]. Wind average velocity is $<12 \mathrm{~m} / \mathrm{s}$, with the strongest winds blowing from the northeast in December-March and weakest values associated with easterly approaching winds, usually blowing in September-November. The dominant sea surface current is the Caribbean current that flows during almost all the year from east to west; an opposite current, the Darien or Colombia current, flows from Panama northeastward [29]. Significant wave height is between 1 and $2 \mathrm{~m}$ and wave climate is dominated by swell waves approaching from the northeast from November to May, and sea (smaller) waves, approaching from the northwest, west-southwest, and southwest, during the remainder of the year. Predominant longshore sediment transport is southwestwardly directed and a minor reversal takes place during rainy periods when southerly winds achieve more importance, giving rise to short erosive waves [30]. Coastal erosion is essentially linked to the impact of hurricanes and cold fronts-the former events impacting the coast from June to November, and latter events from January to March [31].

Mallorquín Swamp is located in the northwest part of the Department of Atlántico (Figure 1), on the western bank of the Magdalena River, close to Barranquilla. It is a shallow estuarine coastal lagoon with an area of around $650 \mathrm{ha}$, surrounded by floodplains and sand dunes. Three species of mangroves have been reported in Mallorquín Swamp: A. germinans, R. mangle, and L. racemosa with a maximum average height of $15.7 \mathrm{~m}$. The most abundant species is A. germinans (71\%), followed by L. racemosa $(21 \%)$, and finally R. mangle (8\%) [32]. Salinity range was $9 \%-22 \%$ in surface water and $14 \%$ o- $50 \%$ o in interstitial water, that is, at a depth between 50 and $100 \mathrm{~cm}$ [32]. The mangrove leaves had cuts and perforations associated with herbivory. The presence of climbing plants was also observed-they generate overweight and strangulation of stems and branches [32]. The system has been affected by coastal erosion, increased 
sedimentation processes, and anthropogenic activities linked to the urbanization of nearby areas and contamination processes due to solid waste and sewage discharges [33-37].

Totumo Swamp (Figure 1), located between the departments of Bolívar and Atlántico, is composed by a main body of water with an approximate extension of 1361.06 ha and presents several mangrove patches on the borders of the swamp. Totumo Swamp presents average salinity values from $0.1 \%$ o to $2 \%$, and thus it is considered a fresh water body [38]. The vegetation adjacent to Totumo Swamp belongs to the dry tropical forest and very dry thorny scrub. Lastly, along the swamp flood plains, an abundant vegetation of Typha dominguensis was observed [38]. The swamp is partially protected by a $5 \mathrm{~km}$ long spit, namely, Galerazamba spit, made up of a wide beach with a gentle slope from $2^{\circ}$ to $5^{\circ}$, which has undergone major morphological changes since its initial description by Francisco J. Fidalgo in 1805 [39-41]. The spit encloses inland lagoons (e.g., La Redonda) that are fed by rainfalls, as well as directly by the sea during the stormy season. La Redonda lagoon, inside the Galerazamba spit, has an average salinity of $23 \%$, suitable for mangrove development [38]. On and nearby the spit, there are several mangrove areas composed of L. racemosa $(77 \%)$, which is located on the edge of the lagoon, and C. erectus $(23 \%)$, which is found at the mouth of the swamp. Mangroves have a shrubby growth, with maximum average heights of $6.1 \mathrm{~m}$ for $L$. racemosa and $5.7 \mathrm{~m}$ for C. erectus. The vegetation is currently under anthropogenic pressure, mainly due to the expansion of the agricultural frontier that has been increasing in recent years, negatively impacting the mangrove forest by illegal logging and successive land reclamation. Presently, the original brackish vegetation is changing towards a typical freshwater vegetation ecosystem because of the reduced inputs of marine waters due to the construction of gates (that are usually closed) at the lagoon inlet entrance [19,38].

North of Cartagena de Indias (Department of Bolívar, Figure 1), there is one of the most important coastal wetland of Colombia, namely, La Virgen Swamp, which has an approximate surface of $20 \mathrm{~km}^{2}$ and a mangrove forest cover of around $824 \mathrm{ha}$, with a main drainage network consisting of 8 streams in the rural area and 20 channels in the urban perimeter of Cartagena de Indias. Four species of mangrove have been reported in La Virgen Swamp: A. germinans (67\%), R. mangle (30\%), L. racemose, and C. erectus that, together, make up 3\% of the swamp. R. mangle is located on the internal border of lagoons and channels; A. germinans is found in the less intervened sites, reaching the limit with the tropical dry forest; $L$. racemosa is mainly found on the edges of abandoned ponds; and C. erectus is only found at the border between the mangrove forest and the mainland vegetation [42]. Salinity varies considerably, and its most frequent peaks are in the range of $0 \%$ o to $35 \%$ [ [42]. The average height of the mangrove plants varies from 1 to $10 \mathrm{~m}$, according to the forest sector [21,43].

The area is subject to various threats such as illegal logging; artificial filling; and terracing for the implementation of fish farming, waste disposal, urbanization, and pollution; for example, La Virgen Swamp receives about $60 \%$ of the Cartagena de Indias wastewaters, around 114,000 $\mathrm{m}^{3} /$ day. Further, because of the reduced capacity of water exchange between the lagoon and the Caribbean Sea, several problems have arisen in the last decades, such as eutrophication, increased salinity, and fish mortality [20,44,45].

\section{Methodology}

The methodology applied to assess the mangrove area changes was supported by multi-date remote-sensed data. Using satellite images, it is possible to identify, calculate, and monitor mangrove areas, as well as the surfaces affected by erosion processes [46-49].

\subsection{Data Used}

To determine the extent of mangrove ecosystems, we used Landsat 5 and 8 multispectral satellite images (TM-thematic mapper, and OLI-operational land) with a spatial resolution of $30 \mathrm{~m}$ in their optical channels available at the United States Geological Survey [50]. The dates of the images varied between 1985 and 2018 (Table 1). The dataset was composed of the OLI sensor bands, already subjected to a complex algorithm of adjustment of the atmospheric effects that was based on parameters estimated 
from the same sensor bands and the application of the model of the second simulation of the satellite signal with the code known as solar vector spectrum (6SV) [51].

The images presented a good resolution due to the lack of cloudiness and atmospheric disturbances. Similarly, Google Earth Pro images and thematic cartography available in DIMAR-CIOH [52], INVEMAR [53], and a layer from the Humboldt Foundation cartographic base were used.

\subsection{Digital Images Analysis}

The manipulation of Landsat images was carried out using ARGIS 10.4. Initially, the coordinate system was defined by processing the georeferencing according to the parameters defined for land mapping in Colombia with the Magna Sirgas Datum Bogotá coordinate system.

The analysis, interpretation, and quantification procedures of the images used were performed using band composition, as well as the normalized difference vegetation index (NDVI), which was calculated using the following equation:

$$
\mathrm{NDVI}=(\mathrm{IVP}-\mathrm{V}) /(\mathrm{IVP}+\mathrm{V})
$$

where IVP and V represent the reflectance values in the near-infrared and red infrastructure bands, respectively. The NDVI varies from -1 to +1 , with negative values and zero representing areas without vegetation [54]. The procedure for delimiting the areas identified as mangrove forests was carried out by manual vectoring on the classified images. This method requires a great deal of interpretation and is time consuming, as each polygon must be determined individually.

Ortho-rectified satellite images were also used to map shoreline position. Shoreline migration was analyzed in ARGIS 10.4 by the Digital Shoreline Analysis System-DSAS 5.0 [55].

Table 1. Details of multispectral remote sensing data and other documents used in this study.

\begin{tabular}{|c|c|c|c|c|c|}
\hline Location Area & $\begin{array}{l}\text { Sensor and/or } \\
\text { Document }\end{array}$ & $\begin{array}{c}\text { Spatial } \\
\text { Resolution } \\
\text { (m)/or Scale }\end{array}$ & $\begin{array}{l}\text { Year/Month/Day } \\
\text { of Acquisition }\end{array}$ & Source & $\begin{array}{c}\text { Cloud Cover } \\
(\%)\end{array}$ \\
\hline \multirow{4}{*}{ Mallorquín Swamp } & Landsat 5-OLI & 30 & $1985 / 01 / 24$ & USGS & $<5$ \\
\hline & Landsat 5-OLI & 30 & $1998 / 05 / 20$ & USGS & $<5$ \\
\hline & Landsat 8-OLI & 30 & $2013 / 04 / 01$ & USGS & $<5$ \\
\hline & Landsat 8-OLI & 30 & 2018/12/05 & USGS & $<10$ \\
\hline \multirow{4}{*}{ Totumo Swamp } & Landsat 5-OLI & 30 & $1985 / 01 / 24$ & USGS & $<5$ \\
\hline & Landsat 5-OLI & 30 & $1998 / 09 / 20$ & USGS & $<5$ \\
\hline & Landsat 8-OLI & 30 & $2013 / 05 / 13$ & USGS & $<5$ \\
\hline & Landsat 8-OLI & 30 & 2018/12/05 & USGS & $<5$ \\
\hline \multirow{4}{*}{ La Virgen Swamp } & Landsat 5-OLI & 30 & $1985 / 01 / 24$ & USGS & $<5$ \\
\hline & Landsat 5-OLI & 30 & $1998 / 09 / 20$ & USGS & $<5$ \\
\hline & Landsat 8-OLI & 30 & $2013 / 05 / 13$ & USGS & $<5$ \\
\hline & Landsat 8-OLI & 30 & 2018/12/05 & USGS & $<5$ \\
\hline \multirow{3}{*}{ All areas } & Unidentified & 4 & All years & $\begin{array}{c}\text { Google } \\
\text { Earth Pro }\end{array}$ & $<5$ \\
\hline & Lidar-Spot $^{1}$ & $1: 50,000$ & All years & DIMAR-CIOH & Unidentified \\
\hline & $\begin{array}{c}\text { Layer } \\
\text { Colombia }^{2} \\
\text { Mangrove }\end{array}$ & $1: 5,000,000$ & 2005 & INVEMAR & Unidentified \\
\hline \multirow{2}{*}{$\begin{array}{c}\text { Mallorquín } \\
\text { Swamp/Totumo Swamp }\end{array}$} & \multirow{2}{*}{ Spot-Aster ${ }^{3}$} & \multirow{2}{*}{30} & 1986 & INVEMAR & Unidentified \\
\hline & & & 2004 & INVEMAR & Unidentified \\
\hline
\end{tabular}

${ }^{1}$ Atlas Geomorfológico del Caribe Colombiano [52]. ${ }^{2}$ Sistema de información para la gestión de los manglares de Colombia SIGMA [56]. ${ }^{3}$ Ordenamiento Ambiental de la Zona Costera del Departamento del Atlántico [53]. 


\subsection{Field Visits}

Detailed field visits were made to the three mangrove forests investigated in this study in order to determine actual predominant plant species, their distribution, their conditions (leaf characteristics and plant average height), and the typology of anthropic activities (road emplacement, expansion of urbanized areas, disposal of waste materials, illegal logging, etc.) and their effects on the environment. Characteristics of mangroves in past investigated time spans were essentially reconstructed from unpublished reports carried out by environmental departmental authorities and research institutes.

\section{Results and Discussion}

\subsection{Mangrove Swamps Evolution}

The evolution of three most relevant mangrove forests along the Department of Atlántico and Bolívar, that is, the Mallorquín, Totumo, and La Virgen swamps, is presented in the following sub-sections.

\subsubsection{Mallorquín Mangrove Swamp}

The mangrove forest of Mallorquín Swamp presented small changes in the period of 1985-1998, a reduction of around 51 ha from 1998 to 2013, and an increase of around 34 ha during the 2013-2018 period (Figure 3, Table 2).

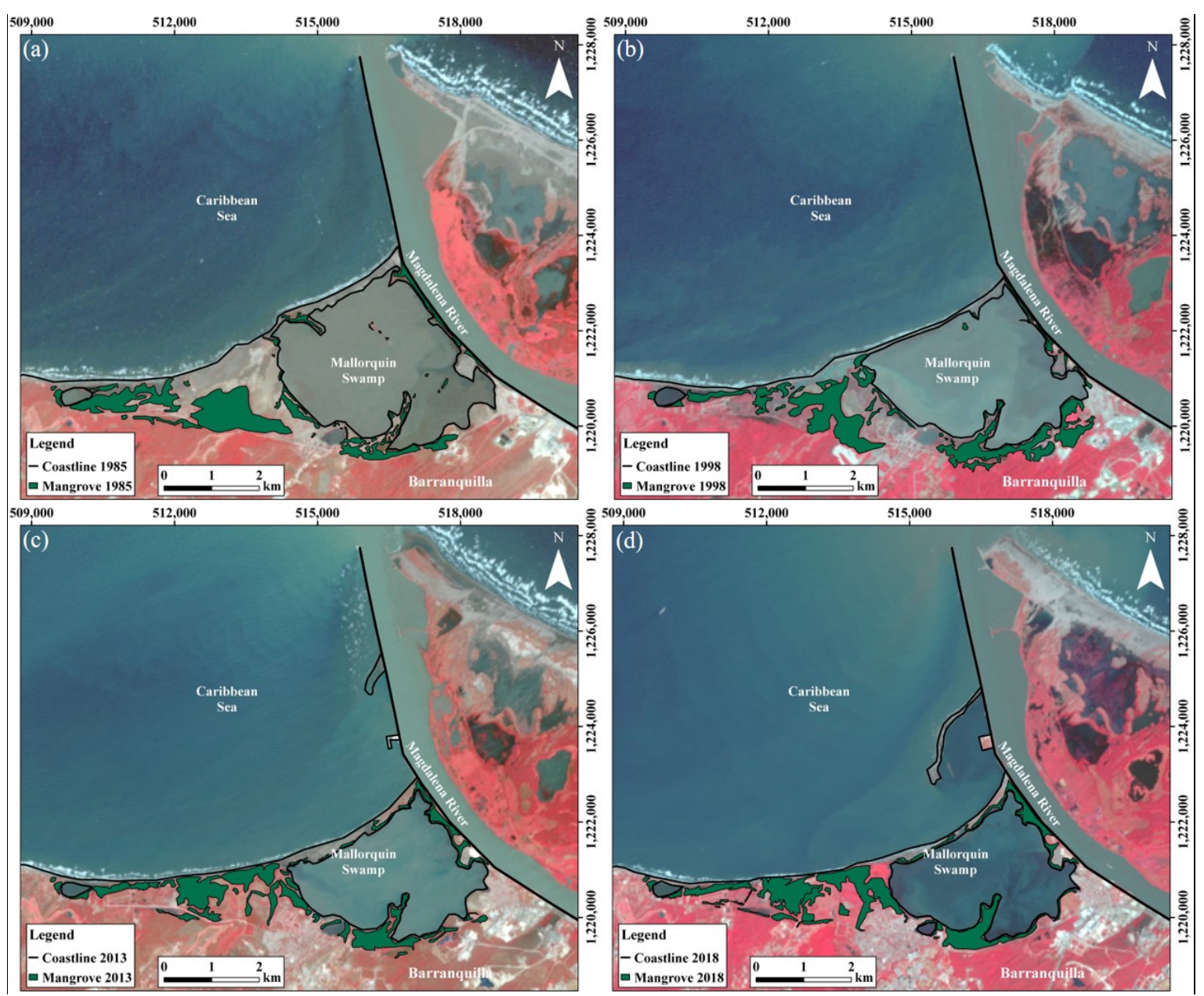

Figure 3. Evolution of the mangrove forest (green) in the Mallorquín swamp (a) 1985, (b) 1998, (c) 2013, and (d) 2018. 
Table 2. Variation of the mangrove forest cover (ha) in the Mallorquín, Totumo, and La Virgen swamps.

\begin{tabular}{cccc}
\hline \multirow{2}{*}{ Year } & \multicolumn{3}{c}{ Mangrove Cover (ha) } \\
\cline { 2 - 4 } & Mallorquín & Totumo & La Virgen \\
\hline 1985 & 302 & 496 & 725 \\
1998 & 304 & 215 & 685 \\
2013 & 253 & 229 & 941 \\
2018 & 287 & 195 & 910 \\
\hline
\end{tabular}

Until the beginning of the 1940s, the swamp had an estuarine regime constituted of different coexisting and connected systems, that is, the Cantagallo, Mallorquín, La Playa, and Manatíes swamps, which presented a wide variety of ecosystems and fishing areas [57,58]. After the construction of the western jetty at the Magdalena River mouth, during the 1925-1935 time span, the sand bar that encloses Mallorquín Swamp suffered—between 1939 and 1987-an erosion rate of $65 \mathrm{~m} /$ year, finally acquiring its current configuration. The swamp recorded a strong hydrologic imbalance due to a deficit in fresh water supplies that were essentially limited to the León stream and direct rainfall [53,59]. The deficiency in water supplies significantly affected the different ecosystems, impacting the fishing activities and the mangrove forest health $[57,58]$.

Concerning the period from 1985 to 1998, fairly unrepresentative changes were reported, that is, a very small increase (Table 2) as a result of the mangrove loss observed at the sand bar that encloses the swamp and the mangrove cover increase recorded in the southern part of the swamp (Figure 3a,b). Despite such small changes, the swamp reflected a stressful environmental condition, mainly due to the diminution of hydrodynamic processes. The effects of such an unfavorable situation continued in following years, and were more evident at the beginning of the 2000s.

In this same period, the area of Mallorquin Swamp was reduced considerably. The bar migrated landward on average $29.5 \mathrm{~m} /$ year, resulting in a period of relevant morphological changes and loss in mangrove cover.

Changes in the hydrodynamic conditions, as observed since the end of the 1980s by Galvis et al. [19,60], were linked to the few continental and marine water supplies, because of the reduced fresh water supplies from the León stream and the lack of permeability of the western jetty at the Magdalena River mouth. This brought to the modification of the mangrove ecosystem, and A. germinans and eurihaline vegetation became the predominant species compared with $R$. mangle, reflecting a process of salinization that continued in following years, reaching interstitial salinity values from $20 \%$ o to $30 \%$, as reported by Galvis et al. and Ulloa-Delgado et al. [60,61]. However, the loss of $R$. mangle was not only associated with the salinity increase but also with erosion processes that led to the loss of trees and beach surfaces, which made the implantation of new $R$. mangle propagules impossible.

In the period from 1998 to 2013, around 51 ha of forest were lost (Table 2) as a result of urban area expansion in the southern part of the swamp $[19,61]$, where illegal forest cutting by local inhabitants, accumulation of solid waste materials, and artificial infilling works were observed (Figure $3 b, c)$. On the other hand, mangrove growth was recorded in the sand bar because of the reduction of coastal erosion (Figure 4) that allowed bar stabilization and propagules implantation and growth.

The most exploited species was L. racemosa, used for the construction of huts to provide shade for tourists visiting local beaches. As for solid waste materials, which prevent the proper development of seedlings and pneumatophores and hence favor a decrease in the self-healing capacity of the forest [62], they essentially came from the Magdalena River that drains a basin of 257,430 km², wherein 724 municipalities are located, representing $80 \%$ of the Colombian population [63]. Further mangrove losses were related to the diminution of fresh water supplies, especially during the 1997-1998 period in which Colombia was greatly impacted by the El Niño phenomenon that led to a generalized decrease of rainfall and river discharges. During the most critical dry period (October 1997 to January 1998), the flow of the Magdalena River fluctuated between $45 \%$ and 70\% in its lower basin [64], considerably decreasing its water contribution to Mallorquín Swamp and the consequent increase of salinity. The 
very narrow strip of $R$. mangle observed in 1998 in the southern, northeastern, and northwestern parts of the swamp was later replaced by a monospecific forest of $A$. germinans, with the presence of few individuals of L. racemosa and C. erectus and xerophytic plants (Prosopis juliflora, Capparis odorantissima, Sarcostema sp., and Stigmaphyllon sp.) [61]. In general, the forest presented mature individuals, but of little height (average: $3.86 \mathrm{~m}$ ) and with leaves characteristic of xerophytic plants [61]. Such a trend continued in 2005, as reported by INVEMAR [53] and GTA [57], but slightly decreased in 2007 when salinity achieved values between $20 \%$ ond $35 \%$ o that allowed $A$. germinans to survive [65] and led to a slow recovery in the general mangrove forest cover [53]. In addition, in 2007, reforestation programs were initiated by the fishing communities with the support of local environmental authorities [53]. The stabilization of the hydrological conditions and the reforestation programs had positive effects that were observed in the following period investigated.

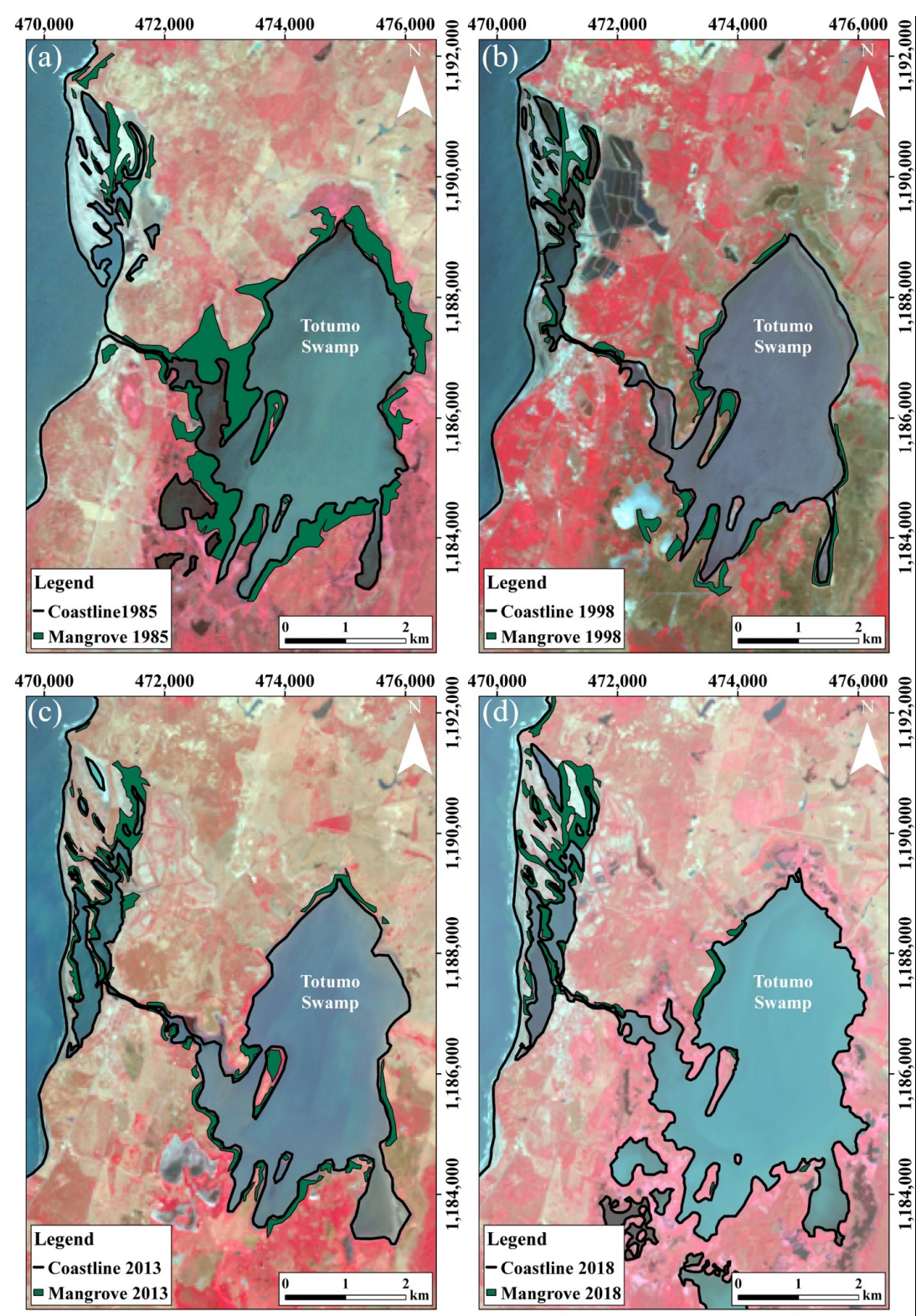

Figure 4. Evolution of the mangrove forest (green) in the Totumo swamp: (a) 1985, (b) 1998, (c) 2013, and (d) 2018.

In the period from 2013 to 2018, an increase in mangrove coverage of around 34 ha was located on the west part of the sand bar and in the southern part of the swamp (Figure 3c,d). In this period, the 
stability of the sandy bar was observed, as a consequence of the growth of a spit, as being connected to the Magdalena western jetty, located to the north of the swamp. This new formed feature protected the bar from incoming waves (Figure 3c,d).

Additionally, the recovery of the mangrove could be related to the reforestation campaigns carried out by different entities [53] and the maintenance of the different channels that communicate the swamp with the Magdalena River. In 2016, the Corporación Autónoma Regional del Atlántico (Local Environmental Authority) carried out activities aimed at the environmental recovery of the swamp by directly cleaning the channels and by installing meshes in the boxcoulverts to reduce waste materials entering in the channels communicating the swamp with the Magdalena River [58]. Presently, an ongoing project is being developed to declare Mallorquín Swamp a protected area [66].

\subsubsection{Totumo Mangrove Swamp}

The mangrove forest of Totumo Swamp presented a reduction of ca. 280 ha in the period from 1985 to 1998, an increase of ca. 13 ha in the period from 1998 to 2013 and a loss of ca. 33 ha during the period from 2013 to 2018 (Figure 4 and Table 2).

The large loss of mangrove cover recorded in the first period (from 1985 to 1998) was related to the transformation of the forest into a freshwater vegetation ecosystem [38]. Most relevant changes were recorded in the northern part of the swamp (Figure 4a,b). Totumo Swamp communicated with the Caribbean Sea through a natural inlet that allowed the entry of salt water, generating ideal conditions for the growth of mangrove [38,53]. However, in the 1970s, gates emplaced at the inlet entrance, $20 \mathrm{~m}$ in width, greatly limited sea water entrance, turning much of Totumo Swamp into a freshwater system (Figure 4) [38,67], which receives supplies from numerous streams, such as Punta Antigua, Lata, Calabria, and Bombo [61]. As a result, during the rainy season, salinity was close to zero and, during dry seasons (i.e., January-May and July-September), salinity increased up to 15\%o [68]. Mangrove plants presented shrubby and stunted forms and did not exceed $2 \mathrm{~m}$ in height. There were observed specimens of $R$. mangle, L. racemosa, C. erectus, and A. germinans, the latter being the most abundant. A considerable decrease of $R$. mangle was observed at the mouth of the swamp, and Typha dominguensis was recorded on the west bank, alternating with C. erectus with rhizomes on the roots, stems, and lower branches [61].

An increase of around 13 ha in mangrove surface was recorded in the period from 1998 to 2013 as a result of mangrove growth on the western side of the swamp, on the Galerazamba spit, as well as a decrease on the eastern side (Figure $4 b, c$ ).

Galerazamba spit has undergone relevant morphological changes since its original description by Francisco J. Fidalgo in 1805 [39-41]. Anfuso et al. [69] reported spit evolution from 1947 to 2013, recording an accretion of around $0.7 \mathrm{~km}^{2}$ and a down drift (i.e., southward) migration of about $80 \mathrm{~m}$. Hence, the increase in the mangrove area was directly related to the growth of the spit that enclosed numerous small lagoons, among which the larger one was La Redonda Swamp, fed by rainfalls and by the sea during stormy season $[39,40]$.

On the eastern side of the swamp, INVEMAR [19] observed in 2004 that the mangrove cover was reduced to a strip of approximately 5 to $10 \mathrm{~m}$ in width, mainly composed of C. erectus and L. racemosa. At this area, the natural mangrove cover was progressively displaced by pastures and macrophytes and human activities as livestock and agriculture [53]. On the southwestern side of the swamp, only a very narrow line of $C$. erectus, with plants about $7.5 \mathrm{~m}$ high, was recorded; no natural regeneration or flowering of mangroves was observed [19].

The mangrove forest of Totumo Swamp degraded in the period from 2013 to 2018, with a loss of around 33 ha (Figure 4c,d). The decrease was mainly observed on the eastern side, whereas the western side showed only a small increase associated with mangrove growth in the lagoons at Galerazamba split. The overall reduction in mangrove cover was undoubtedly related to the loss of water exchange with the Caribbean Sea. This turned Totumo Swamp into a freshwater ecosystem, wherein water is nowadays mainly used for agricultural and livestock activities. The economic interests linked to the 
maintenance of such activities retain the gates at the inlet entrance that was closed to prevent seawater entrance, thus prohibiting the restoration of the original swamp ecosystem.

\subsubsection{La Virgen Mangrove Swamp}

La Virgen mangrove forest presented a reduction of around 40 ha in the period from 1985 to 1998, an increase of around 255 ha in the period from 1998 to 2013, and again a reduction of around 34 ha in the period from 2013 to 2018 (Figure 5, Table 2).
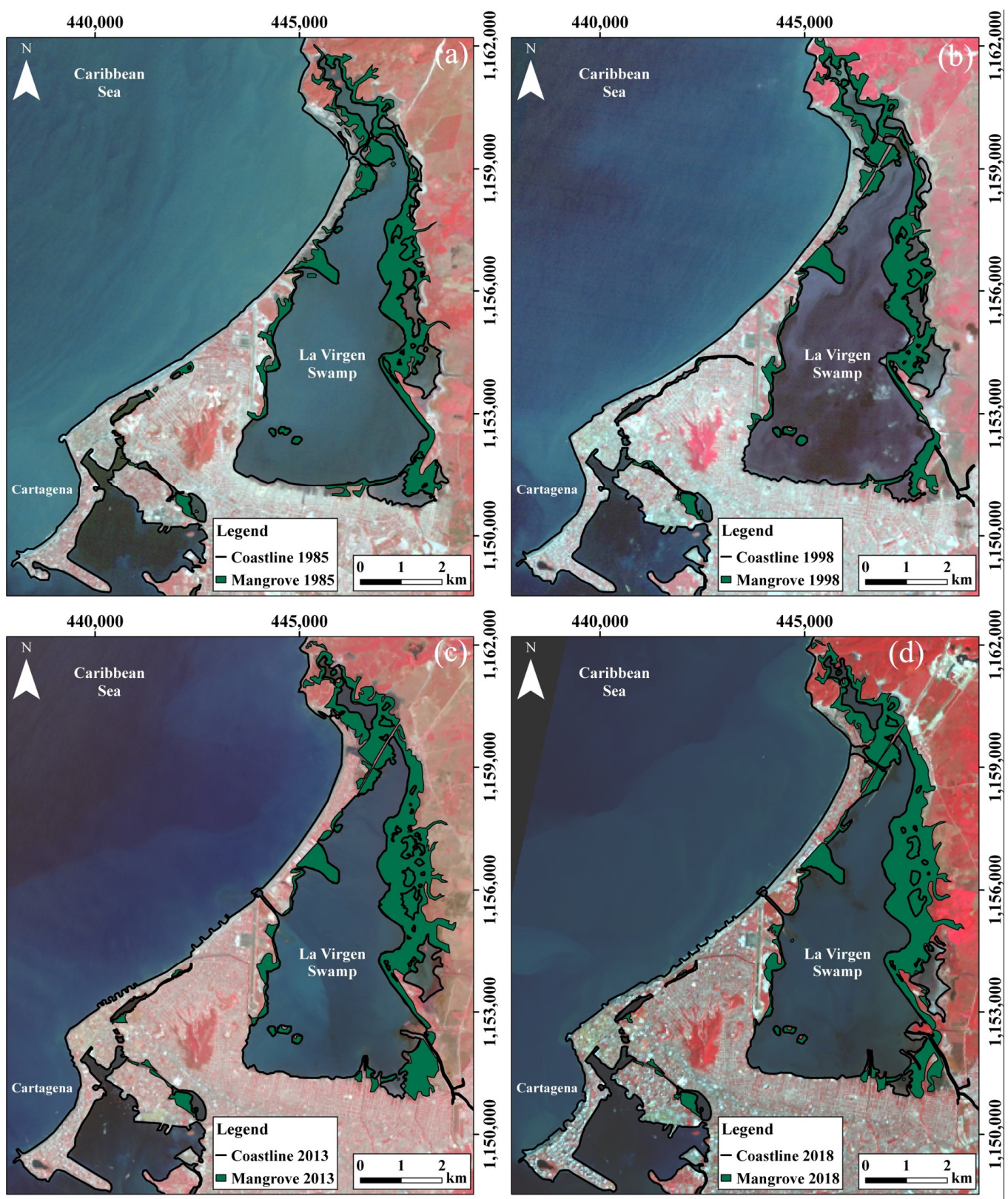

Figure 5. Evolution of the mangrove forest (green) in La Virgen swamp: (a) 1985, (b) 1998, (c) 2013, and (d): 2018.

The mangrove forest of La Virgen presented a reduction of approximately 40 ha in the period from 1985 to 1998 (Table 2). This reduction was mainly observed in the northern part of the swamp (Figure 5a,b) and was associated with different factors that were reported since 1984 by CARDIQUE [70], among them are (i) the accumulation of waste materials, mainly plastics, observed especially at the 
roots of R. mangle [21]; (ii) the illegal logging-for the construction of houses by the communities living on the banks of the swamp-of L. racemose, which consequently suffered a relevant pressure, with mortality values of $92.9 \%$; and (iii) the land filling for urban infrastructure emplacement, such as the construction of a connection runway to the local airport and the roadway Cartagena-Barranquilla, among others $[45,70]$. In the following years, the mentioned roadway greatly affected water exchanges between the swamp and the Caribbean Sea, reducing the existing inlets to a single point located at La Boquilla [43,71]. Therefore, water exchange capacity was significantly reduced, limiting the oxygenation process and altering the constant flow of sediments and organic material, mainly due to the periodic infilling of the inlet, which generated problems such as eutrophication, increased salinity, and fish mortality [44]. In addition, the road construction at the border of the mangrove forest will probably lead to the replacement of native vegetation by other vegetation types, as observed in Punta Mala Bay, Panama [72]. During this investigated period, along and nearby the mentioned roadway, the construction of many resorts and hotels also took place, which was done to satisfy the tourism market demand, as well as the implementation of aquaculture activities (e.g., cultivation of tarpon fish) [71].

In the southern sector, the loss of mangrove areas occurred mainly through landfill processes and, consequently, substitution by urbanization (Figure 5).

Concerning the period from 1998 to 2013, an increase of 255 ha was observed essentially along the eastern border of the swamp (Figure $5 b, c$ ). This mangrove surface increase was linked to the execution of a project, at the end of 2000, which stabilized the La Bocana area to guarantee the permanent water entrance from the Caribbean Sea. The project consisted in the emplacement of different structures at the inlet entrance and along the feeding channels (sand traps, gates, etc.) that favored the recirculation of water within the swamp, improving the level of oxygenation and salinity; in this way, the lagoon recovered the natural ecosystem services [73]. INVEMAR [19] recorded an increase of mangrove vegetation in 2004, which was dominated by $R$. mangle and A. germinans (that together accounted for $97 \%$ of the total amount), followed by L. racemosa and C. erectus. L. racemosa was rare and was usually found on the edges of abandoned ponds, whereas C. erectus was the least frequent and was only located at lagoon borders, along with the mainland vegetation. In addition, in 2004, a reforestation program was carried out, wherein 401,564 plants (of four species of mangroves) were planted in an area of 44.3 ha [19]. Summing up, the reestablishment of the hydrodynamic of the swamp and the implementation of reforestation programs seemed to be the main reasons for the increase in mangrove coverage between 1998 and 2013.

Concerning the last investigated period, from 2013 to 2018 (Figure 5c,d), the swamp presented a reduction of mangrove forests of approximately $30 \mathrm{ha}$, essentially due to the conclusion of the construction, in 2015, of the Cartagena-Barranquilla roadway, as well as a new roadway that included the emplacement of a viaduct $5.39 \mathrm{~km}$ in length, $4.73 \mathrm{~km}$ of which passes over La Virgen swamp [74]. The environmental assessment prior to the construction of the viaduct stated that the structure would impact around 52 ha of swamp surface and 41 ha of mangroves [75]. The National Environmental Licensing Authority (ANLA) authorized in 2015 the logging of 1673 trees, among which 1158 were mangrove trees [75]. The construction company has to compensate such actuations by creating a new green area of $177 \mathrm{ha}$, which could in the next few years increase the total forest coverage [75]. In 2015, the Institute Humboldt and the Foundation Omacha observed, as is the case in the northern zone of the swamp, there is only R. mangle (64\%) on the banks and A. germinans (33\%) on the mainland, whereas four species of mangrove were recorded in the eastern sector: A. germinans (65\%), R. mangle $(33 \%)$, C. erectus $(0,6 \%)$, and L. racemosa $(0.3 \%)$. Inside the forest, there were no permanent flooding events, and hence $A$. germinans dominated (with 97\%), and both C. erectus and L. racemosa were rare and interspersed with $A$. germinans [76]. Further losses of mangrove coverage in the period between 2013 and 2018 were observed in the southern and southeastern areas of the swamp that have been progressively filled in and occupied by human illegal settlements and aquaculture ponds that are generally linked to the illegal occupancy by people displaced by violent events from different territories in Colombia and in Venezuela $[43,45]$. These different factors could together be the cause of the 
mangrove loss recorded in the analyzed time frame. Nowadays, the swamp shows around 775 ha of mangroves, including R. mangle, A. germinans, and L. racemosa [45].

\subsection{Environmental and Natural Concerns}

Oceanographic, climatic, and geomorphological aspects; soil conditions; level and duration of flooding; salinity; and sediment load determine the structure and floristic composition of mangrove forests [77].

Salinity is one of the most important abiotic factors influencing the structure, seedling establishment, and function of mangrove ecosystems, and small changes in salinity can lead to abrupt ecological changes [6,78]. Most mangrove species can grow in fresh water, but growth is stimulated under saline conditions, with optimal seawater concentrations ranging from $5 \%$ o to $50 \%$, depending on the mangrove species [78,79]. High salinity soils limit seed germination and reduce plant growth [80]. The low rates of water loss from the leaves, as a strategy for surviving under hypersaline growth conditions, limit rates of carbon gain affecting the plant growth; as a result of this, individuals of low stature and stunted growth (scrub mangroves) are observed [79]. Therefore, the degree of tolerance to salinity determines the dominance of species within the mangrove forest. Mangrove forests dominated by $R$. mangle can cope with wave strength and salinities close to those of sea water (about $35 \%$ ), those dominated by A. germinans can tolerate and develop under salinity conditions of $60-65 \%$ ond sandier substrates. Although L. racemosa tolerates salinities similar to $R$. mangle, it requires a more open canopy, which allows a greater availability of light for regeneration, and therefore is generally associated with disturbed areas [77]. The effect of the increased salinity on the mangrove species was clearly observed in Mallorquín Swamp, which suffered a loss of diversity-A. germinans and $R$. mangrove were replaced by A. germinans of low stature and a few individuals of L. racemosa [19]. The same condition was also described by Sánchez et al. [65] in a mangrove forest located in the municipality of Puerto Colombia (Colombian Caribbean Sea). The authors detected that in soils with high salinity $(76 \%$ o at $0.3 \mathrm{~m})$, the dominant species was $A$. germinans; meanwhile, $R$. mangle was absent or very scarce. A similar trend, that is, the predominance of $A$. germinans associated with a few individuals of L. racemosa, was also observed in the forest along the Indian River Lagoon (Florida, USA), which is developed on high salinity soils due to low sea water inputs and high evaporation rates [79]. Mangrove mortality due to hypersalinity conditions was reported in the Ciénaga Grande de Santa Marta (Colombia), where sites with dead or dwarfed vegetation had an average soil salinity of $74 \%$, with values between $52 \%$ ond $100 \%$. Basal area and forest biomass volume were inversely correlated with soil salinity [81]. Currently, the Mallorquin swamp presents salinity values between $14 \%$ o- $50 \%$ in interstitial water, which allow the growth of $A$. germinans, $R$. mangle, and L. racemosa [32]. In addition, new sandy bodies are being formed in front of Mallorquín Swamp, where mangrove seedlings are observed (Figures $3 \mathrm{~d}$ and $6 \mathrm{a}$ ). This could generate ideal conditions prone to the increase of this mangrove forest. However, the presence of solid waste is one of the main problems that this forest presents; therefore, cleaning and educational campaigns should be carried out in the surrounding communities and also should be devoted to the tourists that visit the forest (Figure 6b). 


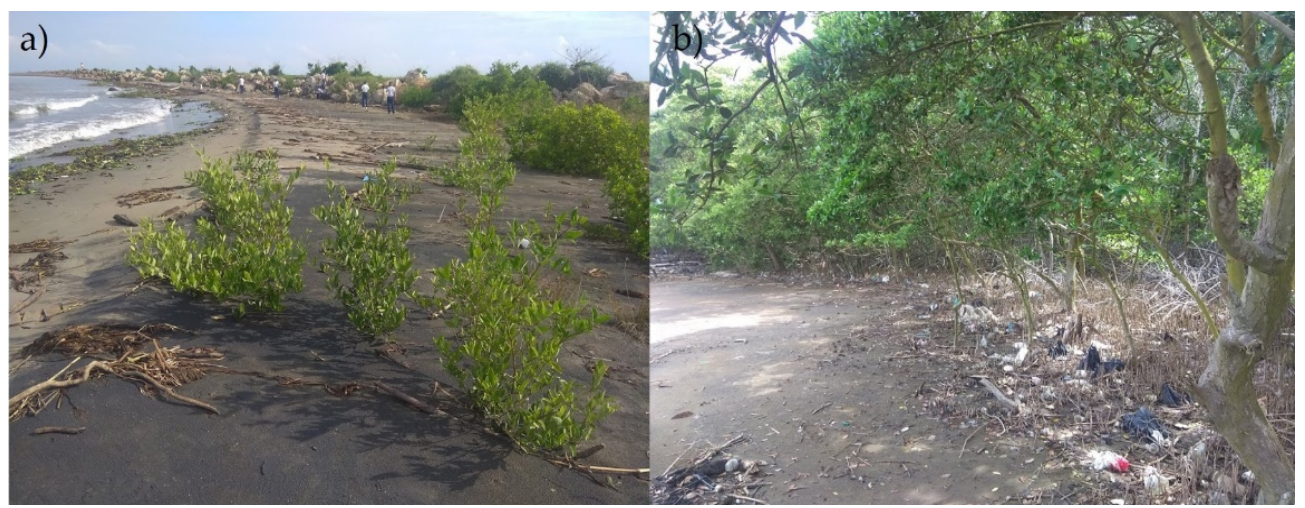

Figure 6. (a) Mangrove seedlings growing in the new sand bar, and (b) plastic waste observed in the mangrove forest of Mallorquín Swamp.

The mangrove, as a facultative halophyte plant, can tolerate fresh water conditions for a limited time but not during its entire life cycle $[82,83]$. The flowing of seawater into the mangrove forest system reduces the possibility of survival for plant species that are not salt tolerant [82]. The mangrove forest of Totumo Swamp was transformed on its eastern side into an ecosystem dominated by freshwater plants (Typha dominguensis and Eichhornia crassipes) due to the loss of seawater input that brought salinity to zero (Figure 7a); meanwhile, mangrove remnants were recorded on its western side that is characterized by brackish water conditions (Figure 7b). La Virgen Swamp was affected mainly by the construction of a road that impedes the normal exchange of water with the Caribbean Sea. The swamp receives about $60 \%$ of the city wastewater, which has an approximate volume of $114,000 \mathrm{~m}^{3} /$ day $[44,45]$. The lack of communication with the Caribbean Sea generated an increase in wastewater concentration, generating eutrophication processes that affected the mangrove forest.

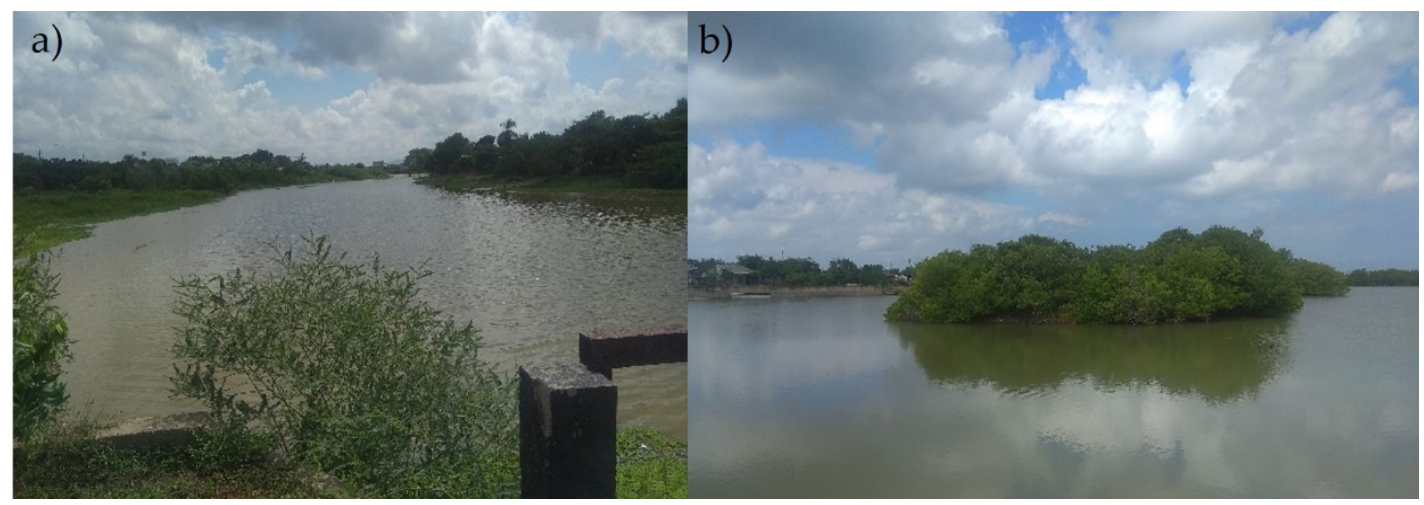

Figure 7. (a) Eastern side of Totumo Swamp characterized by fresh water conditions; (b) mangrove remnants (Rhizophora mangle) in the western side of Totumo Swamp characterized by brackish water conditions.

Deforestation is considered one of the main anthropogenic causes of mangrove degradation [84]. Colombia has the highest annual rate of deforestation in South America, showing values between 1.1\% and $0.6 \%$ for $1980-1990$ and $2000-2005$ periods versus average values of $0.69 \%$ and $0.18 \%$ observed in South America [85]. In Colombia, mangrove areas have been converted mainly into agricultural land, ponds for aquaculture, and urban development (mainly for tourism). Illegal logging has been reported for the three mangrove forests investigated in this paper (Mallorquín, La Virgen, and Totumo), but each one was associated with different activities.

In Mallorquín Swamp, the logging was particularly linked to an increase in urban growth, mainly in the southern part of the swamp (Figure 3d). In La Virgen Swamp (Figure 8a) urban growth for 
tourism, road construction (Figure $8 b$ ), aquaculture, and the use of wood for house building were the main factors associated with the felling of the mangrove forest. In Totumo Swamp, the expansion of the agricultural frontier and the increase in livestock activity on the margins of the swamp were the main factors associated with the felling of the mangrove forest. With respect to land uses in Totumo Swamp, they include extensive livestock farming (5209.43 ha), annual or seasonal crops (53.75 ha), pasture cultivation (3049.85 ha), and aquaculture (155.82 ha) [38].

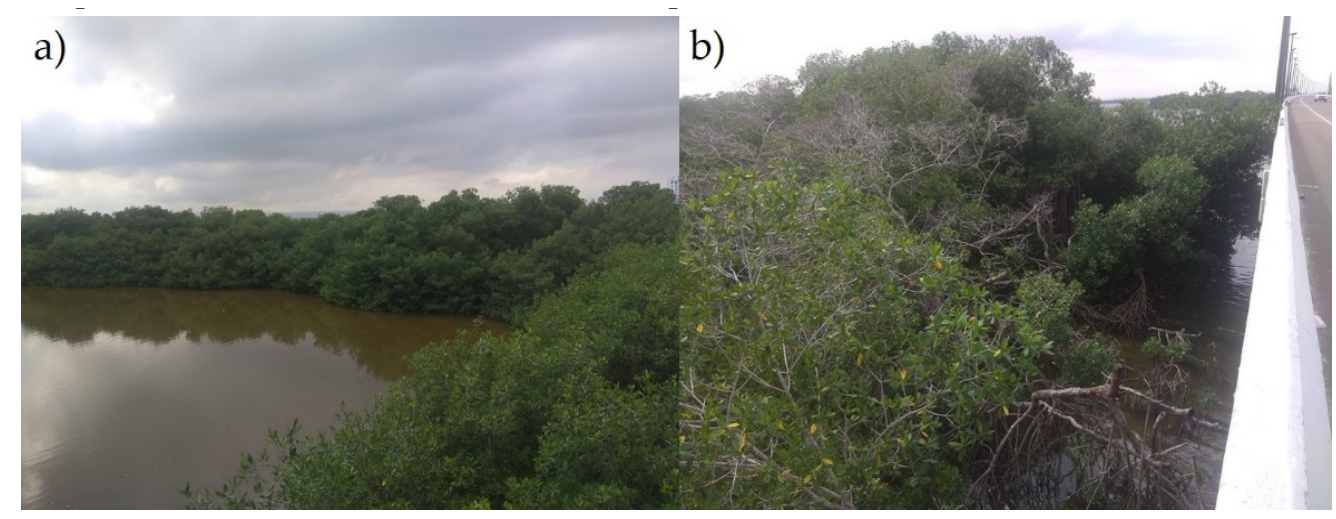

Figure 8. (a) Mangroves (R. mangle) in good condition in the west sector of La Virgen Swamp; (b) mangrove cutting due to the construction of the viaduct over La Virgen Swamp.

Deforestation modifies the mangrove phytogeographic landscape and reduces its biological diversity [84]. Deforestation not only decreases the number of mangrove specimens, but also produces ecological effects on the forest, such as stunted and shrubby growth, canopy opening, stem mortality, decreased regeneration of harvested species, and changes in species composition, among others [86]. The extraction of woody and non-woody products has degraded many areas of mangroves, resulting in the development of plants of low height and thin diameter [85], as reported mainly in the Mallorquín and Totumo swamps. Mangrove deforestation is linked to the lack of adequate methods to assess their economic value; this has led people to consider them as worthless wastelands and as unhealthy risk areas that should be adapted to alternative and more lucrative uses [84].

Mangrove forests are also subject to natural disturbance related to changes in the amount and seasonality of rainfall. This is one of the most relevant factors in the Colombian Caribbean coast, an example being the intensification of the El Niño phenomenon, which generates decreases in the productivity of mangrove forests dominated by $R$. mangle and, in the long term, their replacement by A. germinans [77]. This was observed in the mangrove forest of Mallorquín Swamp that, due to alterations in its hydrology caused by anthropic activities (e.g., construction of the western jetty at the Magdalena River mouth) and natural phenomena such as a relevant reduce of precipitations due to El Niño (1997-1998), recorded not only alterations/degradation in its cover, but also in its composition becoming a monospecific forest consisting only of $A$. germinans.

Mortality events associated with climate extremes (e.g., tropical cyclones and El Niño and La Niña phenomena) could increase in the coming years because mangroves are important sentinels of global climate change processes [87].

\section{Conclusions}

The results obtained in the framework of this paper show how, during different periods of time, mangrove forests at localities investigated in the Colombian Caribbean Sea have been impacted by diverse and complex anthropogenic activities and natural disturbances. Although natural disturbances such as the El Niño phenomenon have greatly affected, at times, the cover and the structure of mangrove forests, human activities were the main cause of degradation and loss. Alterations in the hydrology of swamps, which lead to increases or decreases in salinity, urban growth, illegal logging, 
expansion of agricultural frontiers, and road construction, were the main causes associated with the loss of mangrove cover.

Although losses of mangrove covers were observed in all investigated sites, it is worth noting that different activities carried out by local environmental authorities, together with local inhabitants, favored mangrove forest cover stabilization and, at places and times, led to an increase, such as in the Mallorquín and La Virgen swamps. In Totumo Swamp, different economic interests, essentially linked to agricultural activities, prevented mangrove forest recover. At many places, illegal activities such as logging continue to affect the mangrove forests investigated in this paper, and thus it is mandatory for the Colombian environmental authorities to develop strategies aimed not only at protecting and recovering these ecosystems, but also at raising awareness among the local inhabitants concerning the ecological value of these ecosystems, as well as their importance in coastal adaptation and mitigation function of climate change-related processes.

Author Contributions: Conceptualization, H.S.M., D.A.V.D. and H.J.B.-A.; Data curation, G.A., R.P.M.; Formal analysis, L.P., D.A.V.D., H.S.M. and H.J.B.-A.; Methodology, D.A.V.D., L.P., R.P.M. and G.A.; Writing-original draft, L.P., R.P.M., H.J.B.-A. and G.A. All authors have read and agreed to the published version of the manuscript.

Funding: This research received no external funding.

Acknowledgments: This research is a contribution to the Andalusia PAI Research Group RNM-328, the RED PROPLAYAS network, Universidad Simón Bolívar (Barranquilla, Colombia), Escuela Naval de Suboficiales ARC Barranquilla, Universidad de la Costa (CUC), and the Center for Marine and Limnological Research of the Caribbean CICMAR (Barranquilla, Colombia).

Conflicts of Interest: The authors declare no conflict of interest.

\section{References}

1. Sanderman, J.; Hengl, T.; Fiske, G.; Solvik, K.; Adame, M.F.; Benson, L.; Bukoski, J.J.; Carnell, P.; Cifuentes-Jara, M.; Donato, D.; et al. A global map of mangrove forest soil carbon at $30 \mathrm{~m}$ spatial resolution. Environ. Res. Lett. 2018, 13, 055002. [CrossRef]

2. Carugati, L.; Gatto, B.; Rastelli, E.; Martire, M.L.; Coral, C.; Greco, S.; Danovaro, R. Impact of mangrove forests degradation on biodiversity and ecosystem functioning. Sci. Rep. 2018, 8, 13298. [CrossRef] [PubMed]

3. Barbier, E.B. The protective service of mangrove ecosystems: A review of valuation methods. Mar. Pollut. Bull. 2016, 109, 676-681. [CrossRef] [PubMed]

4. Chauhan, H.B. Mangrove Inventory, Monitoring, and Health Assessment. In Coastal Wetlands: Alteration and Remediation; Frinkl, C., Makouski, C., Eds.; Springer: Cham, Switzerland, 2017; pp. 573-630.

5. Jennerjahn, T.C.; Gilman, E.; Krauss, K.W.; Lacerda, L.D.; Nordhaus, I.; Wolanski, E. Mangrove Ecosystems under Climate Change. In Mangrove Ecosystems: A Global Biogeographic Perspective; Rivera-Monroy, V., Lee, S., Kristensen, E., Twilley, R., Eds.; Springer: Cham, Switzerland, 2017; pp. 211-244.

6. Osland, M.; Feher, L.; Lopéz-Portillo, J.; Day, R.; Suman, D.; Guzmán, J.; Rivera-Monroy, V. Mangrove forests in a rapidly changing world: Global change impacts and conservation opportunities along the Gulf of Mexico coast. Estuar. Coast. Shelf Sci. 2018, 214, 120-140. [CrossRef]

7. Thomas, N.; Lucas, R.; Bunting, P.; Hardy, A.; Rosenqvist, A.; Simard, M. Distribution and drivers of global mangrove forest change, 1996-2010. PLoS ONE 2017, 12, e0179302. [CrossRef] [PubMed]

8. Costanza, R.; de Groot, R.; Sutton, P.; van der Ploeg, S.; Anderson, S.J.; Kubiszewski, I.; Farber, S.; Turner, R.K. Changes in the global value of ecosystem services. Glob. Environ. Chang. 2014, 26, 152-158. [CrossRef]

9. Jia, M.; Wang, Z.; Zhang, Y.; Mao, D.; Wang, C. Monitoring loss and recovery of mangrove forests during 42 years: The achievements of mangrove conservation in China. Int. J. Appl. Earth Obs. Geoinf. 2018, 73, 535-545. [CrossRef]

10. Polidoro, B.A.; Carpenter, K.E.; Collins, L.; Duke, N.C.; Ellison, A.M.; Ellison, J.C.; Farnsworth, E.J.; Fernando, E.S.; Kathiresan, K.; Koedam, N.E.; et al. The loss of species: Mangrove extinction risk and geographic areas of global concern. PLoS ONE 2010, 5, e10095. [CrossRef]

11. Feller, I.C.; Friess, D.A.; Krauss, K.W.; Lewis, R.R. The state of the world's mangroves in the 21st century under climate change. Hydrobiologia 2017, 803, 1-12. [CrossRef] 
12. De Lacerda, L.D.; Borges, R.; Ferreira, A.C. Neotropical mangroves: Conservation and sustainable use in a scenario of global climate change. Aquat. Conserv. Mar. Freshw. Ecosyst. 2019, 29, 1347-1364. [CrossRef]

13. De Almeida, L.T.; Olímpio, J.L.S.; Pantalena, A.F.; de Almeida, B.S.; de Oliveira Soares, M. Evaluating ten years of management effectiveness in a mangrove protected area. Ocean Coast. Manag. 2016, 125, $29-37$. [CrossRef]

14. Lewis, R.; Brown, B.; Flynn, L. Methods and Criteria for Successful Mangrove Forest Rehabilitation. In Coastal Wetlands: An Integrated and Ecosystem Approach; Perillo, G., Wolanski, E., Cahoon, D., Hopkinson, C., Eds.; Elsevier: Amsterdam, The Netherlands, 2019; pp. 863-887.

15. Palacios, M.L.; Cantera, J.R. Mangrove timber use as an ecosystem service in the Colombian Pacific. Hydrobiologia 2017, 803, 345-358. [CrossRef]

16. Polanía, J.; Urrego, L.E.; Agudelo, C.M. Recent advances in understanding Colombian mangroves. Acta Oecologica 2015, 63, 82-90. [CrossRef]

17. Instituto de investigaciones marinas y costeras (INVEMAR). Diagnóstico y Evaluación de la Calidad de Aguas Marinas y Costeras en el Caribe y Pacífico Colombianos; INVEMAR: Santa Marta, Colombia, 2015; pp. 1-315.

18. Bolívar-Anillo, H.J.; Sánchez, H.; Fernandez, R.; Villate, D.; Anfuso, G. An Overview on Mangrove Forests Distribution in Colombia: An Ecosystem at Risk. J. Aquat. Sci. Mar. Biol. 2019, 2, 16-18.

19. Instituto de investigaciones marinas y costeras (INVEMAR). Actualizacion y Ajuste del Diagnóstico y Zonificación de los Manglares de la Zona Costera del Departamento del Atlantico, Caribe Colombiano; INVEMAR: Santa Marta, Colombia, 2005; pp. 1-191.

20. Corporacion Autonoma Regional del Canal del Dique. Zonificación Definitiva de las Áreas de Manglar del Departamento de Bolívar para la Conservación y el Manejo Sostenible; CARDIQUE: Cartagena de Indias, Colombia, 2001; pp. 1-70.

21. Corporación Autónoma Regional del Canal del Dique. Diagnostico, Zonificación y Planificación Estrategica de las Areas de Manglar de Bolívar; CARDIQUE: Cartagena de Indias, Colombia, 1998; pp. 1-176.

22. Andrade, C. Cambios Recientes del Nivel del Mar en Colombia. In Deltas de Colombia: Morfodinámica y Vulnerabilidad Ante el Cambio Global; Restrepo, J., Ed.; EAFIT Univ. Press: Medellin, Colombia, 2008; pp. 103-122.

23. Solano, J.M.; Barros Henríquez, J.A.; Roncallo Fandiño, B.; Arrieta Pico, G. Requerimientos hídricos de cuatro gramíneas de corte para uso eficiente del agua en el Caribe seco colombiano. Cienc. y Tecnol. Agropecu. 2015, 15, 83. [CrossRef]

24. Instituto de Hidrología, Meteorología y Estudios Ambientales (IDEAM). Atlas Climatológico de Colombia. Available online: http://atlas.ideam.gov.co/visorAtlasClimatologico.html (accessed on 19 July 2019).

25. Hurtado Montoya, A.F.; Mesa Sánchez, Ó.J. Cambio climatico y variabilidad espacio-temporal de la precipitación en Colombia. Rev. EIA 2015, 11, 131-150.

26. Andrade Amaya, C.A.; Barton, E.D. Sobre la existencia de una celda de circulación atmosférica sobre el Caribe y su efecto en las corrientes de Ekman del Caribe suroccidental. Boletín Científico CIOH 2013, 31, 73-94. [CrossRef]

27. Philander, S. Atlantic Ocean Equatorial Currents. In Ocean Currents; Steele, J., Thorpe, S., Turekian, K., Eds.; Elsevier: London, UK, 2001; pp. 188-191.

28. Instituto de Hidrología, Meteorología y Estudios Ambientales (IDEAM)-Universidad Nacional de Colombia. La Variabilidad Climática y el Cambio Climático en Colombia; IDEAM: Bogotá, Colombia, 2018; pp. 1-53.

29. Thomas, Y. Climatología Marina, Presión Atmosférica, Viento y Olas para las Aguas Territoriales Bajo Jurisdicción Colombiana. 8-19 N y 69-84 W.; Datos TOPEXPOSEIDON; Laboratorie de Géographie Physique (CNRS): París, France, 2006; p. 69.

30. Correa, I.; Morton, R. Coasts of Colombia U.S. Department of the Interior USGS, St. Petersburg, Florida, USA, 2011. Available online: http://coastal.er.usgs.gov/coasts-colombia/ (accessed on 19 July 2019).

31. Ortiz-Royero, J.C.; Otero, L.J.; Restrepo, J.C.; Ruiz, J.; Cadena, M. Cold fronts in the Colombian Caribbean Sea and their relationship to extreme wave events. Nat. Hazards Earth Syst. Sci. 2013, 13, 2797-2804. [CrossRef]

32. Instituto de investigaciones marinas y costeras (INVEMAR). Evaluación de la Calidad Ambiental de los Manglares de La Ciénaga Mallorquín, Departamento del Atlántico; INVEMAR: Santa Marta, Colombia, 2015; pp. 1-32.

33. Arrieta, L.; de la Rosa, J. Estructura de la comunidad íctica de la ciénaga de Mallorquín, Caribe Colombiano. Bol. Investig. Mar. y Costeras 2003, 32, 231-242. [CrossRef] 
34. Páez, C. Análisis de las dimensiones del desarrollo sostenible en la ciénaga de Mallorquín. Modul. Arquit. 2015, 14, 63-84.

35. Castro-Rodríguez, E.; León-Luna, I.; Pinedo-Hernández, J. Biogeochemistry of mangrove sediments in the Swamp of Mallorquin, Colombia. Reg. Stud. Mar. Sci. 2018, 17, 38-46. [CrossRef]

36. Fuentes-Gandara, F.; Pinedo-Hernández, J.; Marrugo-Negrete, J.; Díez, S. Human health impacts of exposure to metals through extreme consumption of fish from the Colombian Caribbean Sea. Environ. Geochem. Health 2018, 40, 229-242. [CrossRef] [PubMed]

37. Portz, L.; Manzolli, R.; Andrade, C.F.; Villate Daza, D.; Bolivar, D.B.; Alcantara-Carrio, J. Assessment of heavy metals pollution $(\mathrm{Hg}, \mathrm{Cr}, \mathrm{Cd}, \mathrm{Ni})$ in the sediments of Mallorquin lagoon-Barranquilla, Colombia. J. Coast. Res. 2020, in press.

38. Instituto Colombiano de Desarrollo Rural. Plan de Manejo y Ordenación Pesquera del Humedal Ciénaga del Totumo; Universidad Jorge Tadeo Lozano: Cartagena de Indias, Colombia, 2011; pp. 1-242.

39. Carvajal, A. Caracterización físico-biótica del litoral del departamento del Atlántico. In Caracterización Físico-Biótica del Litoral Caribe Colombiano; DIMAR-CIOH, Ed.; Dirección General Marítima: Cartagena de Indias, Colombia, 2009; pp. 97-110.

40. Orejarena Rondón, A.F.; Afanador Franco, F.; Ramos de la Hoz, I.; Conde Frías, M.; Restrepo López, J.C. Evolución morfológica de la espiga de Galerazamba, Caribe colombiano. Boletín Científico CIOH 2015, 123-144. [CrossRef]

41. Anfuso, G.; Rangel-Buitrago, N.; Correa, I. Evolution of sandspits along the Caribbean coast of Colombia: Natural and human influences. In Sand and Gravel Spits; Randazzo, G., Jackson, D.W.T., Cooper, J.A.G., Eds.; Springer: New York, NY, USA, 2015; pp. 1-19.

42. Instituto Humboldt-Fundación Omacha. Aplicación de Criterios Biológicos y Ecológicos para la Identificación, Caracterización y Establecimiento de Límites de Humedales en la Ventana de Estudio: Ciénaga de La Virgen; Instituto Humboldt-Fundación Omacha: Bogotá, Colombia, 2015; pp. 1-50.

43. Agudelo, C. Estructura de los Bosques de Manglar del Departamento de Bolívar y su Relación con Algunos Parametros Abioticos. Bachelor's Degree Thesis in Marine Biology, Univeridad Jorge Tadeo Lozano, Bogotá, Colombia, 2000.

44. Maldonado, W.; Baldiris, I.; Díaz, J. Evaluación de la calidad del agua en la Ciénaga de la Virgen (Cartagena, Colombia) durante el período 2006-2010*. Cienc. Exactas y Apl. 2011, 9, 79-87.

45. Carbal Herrera, A.; Muñoz Carbal, J.; Solar Cumplido, L. Valoración económica integral de los bienes y servicios ambientales ofertados por el ecosistema de manglar ubicado en la Ciénaga de la Virgen. Cartagena-Colombia. Sabercienc. y Lib. 2015, 10, 125-146.

46. Pavithra, B.; Kalaivani, K.; Ulagapriya, K. Remote sensing techniques for mangrove mapping. Int. J. Eng. Adv. Technol. 2019, 8, 27-30.

47. Heumann, B.W. Satellite remote sensing of mangrove forests: Recent advances and future opportunities. Prog. Phys. Geogr. 2011, 35, 87-108. [CrossRef]

48. Khairuddin, B.; Yulianda, F.; Kusmana, C. Degradation Mangrove by Using Landsat 5 TM and Landsat 8 OLI Image in Mempawah Regency, West Kalimantan Province year 1989-2014. Procedia Environ. Sci. 2016, 33, 460-464. [CrossRef]

49. Lymburner, L.; Bunting, P.; Lucas, R.; Scarth, P.; Alam, I.; Phillips, C.; Ticehurst, C.; Held, A. Mapping the multi-decadal mangrove dynamics of the Australian coastline. Remote Sens. Environ. 2020, 238, 111185. [CrossRef]

50. U.S. Geological Survey. Available online: https://earthexplorer.usgs.gov (accessed on 15 July 2019).

51. Vermote, E.; Justice, C.; Claverie, M.; Franch, B. Preliminary analysis of the performance of the Landsat 8/OLI land surface reflectance product. Remote Sens. Environ. 2016, 185, 46-56. [CrossRef] [PubMed]

52. Afanador Franco, F.; Carvajal Díaz, A.F.; Franco Arias, D.A.; Orozco Quintero, F.J.; Pacheco Gómez, J.D.; Santos Barrera, Y. Atlas Geomorfológico del Litoral Caribe Colombiano; Dirección General Marítima: Cartagena de Indias, Colombia, 2013; pp. 1-216.

53. Instituto de investigaciones marinas y costeras (INVEMAR). Ordenamiento Ambiental de la Zona Costera del Departamento del Atlántico; INVEMAR: Santa Marta, Colombia, 2007; pp. 1-583.

54. Rouse, J.W.; Hass, R.H.; Schell, J.A.; Deering, D.W.; Harlan, J.C. Monitoring The Vernal Advancement and Retrogradation (Greenwave Effect) of Natural Vegetation; Final Report; NASA/GSFC: Greenbelt, MA, USA, 1974; pp. 1-137. 
55. Thieler, E.R.; Himmelstoss, E.A.; Zichichi, J.L.; Ergul, A. The Digital Shoreline Analysis System (DSAS) Version 4.0-an ArcGIS Extension for Calculating Shoreline Change (ver. 4.4 July 2017); U.S. Geological Survey Open-File Report 2008-1278; USGS: Reston, VA, USA, 2017.

56. Instituto de investigaciones marinas y costeras (INVEMAR). El Sistema de Información para la Gestión de los Manglares en Colombia SIGMA. Available online: http://sigma.invemar.org.co/ (accessed on 15 July 2019).

57. Grupo de investigación en tecnologías del agua GTA. Análisis Sobre el Manejo Integrado del Recurso Hídrico en la Ciénaga de Mallorquín; GTA: Barranquilla, Colombia, 2005; pp. 1-323.

58. Corporación Autónoma Regional del Atlántico. Documentación del Estado de las Cuencas Hidrográficas en el Departamento del Atlántico; CRA: Barranquilla, Colombia, 2007; pp. 1-114.

59. Martinez, J.O.; Pilkey, O.H.; Neal, W.J. Rapid formation of large coastal sand bodies after emplacement of Magdalena river jetties, northern Colombia. Environ. Geol. Water Sci. 1990, 16, 187-194. [CrossRef]

60. Galvis, O.; Ramiréz, F.; Vacca, V.; Herrera, O.; Bolaño, F.; Arteta, V.; Rodríguez, L.; Jiménez, M.; Vergara, A. Primera fase del programa para la rehabilitación integral de la ciénaga de Mallorquín. Dugandia 1989, 1, 10-12.

61. Ulloa-Delgado, G.; Sanchez-Paez, H.; Gil-Torres, W.; Pino-Rengifo, J.; Rodriguez-Cruz, H.; Alvarez-Leon, R. Conservación y Uso Sostenible de los Manglares del Caribe Colombiano; Sanchez-Paez, H., Ulloa-Delgado, G., Alvarez-León, R., Eds.; Ministerio del Medio Ambiente: Bogotá, Colombia, 1998; pp. 1-224.

62. Ivar do Sul, J.A.; Costa, M.F.; Silva-Cavalcanti, J.S.; Araújo, M.C.B. Plastic debris retention and exportation by a mangrove forest patch. Mar. Pollut. Bull. 2014, 78, 252-257. [CrossRef] [PubMed]

63. Restrepo, J.D.; Kjerfve, B. Magdalena river: Interannual variability (1975-1995) and revised water discharge and sediment load estimates. J. Hydrol. 2000, 235, 137-149. [CrossRef]

64. Corporación Andina de Fomento. El fenomeno El Niño 1997-1998: Memoria, Retos y Soluciones: Colombia; CAF: Caracas, Venezuela, 2000; pp. 1-242.

65. Sánchez, H.; Bolívar-Anillo, H.J.; Villate-Daza, D.; Escobar-Olaya, G.; Anfuso, G. Influencia de los impactos antrópicos sobre la evolución del bosque de manglar en Puerto Colombia ( Mar Caribe colombiano ). Rev. Latinoam. Recur. Nat. 2019, 15, 1-16.

66. Contraloria distrital de Barranquilla. Informe del Estado de los Recursos Naturales y del Ambiente de Barranquilla; Contraloria Distrital: Barranquilla, Colombia, 2018; pp. 1-49.

67. Niño, L. Los acuerdos de pesca responsable en el humedal ciénaga del Totumo (Atlántico-Bolívar). In Proceedings of the Biodiversidad y Turismo para un Desarrollo Sostenible; Olivero, J., de León, J., Eds.; AECID: Cartagena de Indias, Colombia, 2011; pp. 111-125.

68. Narváez, J.; Acero, A.; Blanco, J. Variación morfométrica en poblaciones naturalizadas y domesticadas de la Tilapia del Nilo Oreochromis niloticus (Teleostei: Cichlidae) en el norte de Colombia. Rev. la Acad. Colomb. Cienc. 2005, 29, 383-394.

69. Anfuso, G.; Rangel-Buitrago, N.; Correa, I. Evolution of four different sandy features along the Caribbean littoral of Colombia. In Sand and Gravel Spits Coastal Research Library; Randazzo, G., Jackson, D., Cooper, A., Eds.; Springer: New York, NY, USA, 2015; pp. 1-21.

70. Corporación Autónoma Regional del Canal del Dique. Actualización de la Zonificación de Manglares en la Jurisdicción de CARDIQUE.; CARDIQUE: Cartagena de Indias, Colombia, 2007; pp. 1-148.

71. Torregroza, E.; Gómez, A.; Borja, F. Aplicación del sistema de información geográfico quantum GIS en la regionalización ecológica de la cuenca ciénaga de la Virgen (Cartagena de Indias-Colombia). RITI J. 2014, 2 , 1-13.

72. Benfield, S.L.; Guzman, H.M.; Mair, J.M. Temporal mangrove dynamics in relation to coastal development in Pacific Panama. J. Environ. Manage. 2005, 76, 263-276. [CrossRef]

73. Moor, R.; van Maren, M.; van Laarhoven, C. A controlled stable tidal inlet at Cartagena de Indias, Colombia. Terra Aqua 2002, 88, 3-14.

74. Vélez, S. Estudio de caso: Concesión vial Cartagena-Barranquilla y Circunvalar de la Prosperidad. Análisis de política pública. Derecho y Econ. 2018, 49, 173-207.

75. Autoridad Nacional de Licencias Ambientales. Resolución 1290 de 2015; ANLA: Bogotá, Colombia, 2015; pp. 1-171.

76. Instituto Humboldt-Fundación Omacha. Caracterización Biológica y Ecológica de las Comunidades de Plantas Acuáticas, Plantas Terrrestres y Macroinvertebrados, y Caracterización Físico-Química de las Aguas de la Ventana de Estudio de la Ciénaga de la Virgen; Instituto Humboldt-Fundación Omacha: Bogotá, Colombia, 2015; pp. 1-109. 
77. Mira, J.D.; Urrego, L.E.; Monsalve, K. Determinantes naturales y antrópicos de la distribución, estructura y composición florística de los manglares de la Reserva Natural Sanguaré, Colombia. Rev. Biol. Trop. 2019, 67, 810-824. [CrossRef]

78. Ball, M.C. Interactive effects of salinity and irradiance on growth: Implications for mangrove forest structure along salinity gradients. Trees-Struct. Funct. 2002, 16, 126-139. [CrossRef]

79. Sobrado, M.A.; Ewe, S.M.L. Ecophysiological characteristics of Avicennia germinans and Laguncularia racemosa coexisting in a scrub mangrove forest at the Indian River Lagoon, Florida. Trees-Struct. Funct. 2006, 20, 679-687. [CrossRef]

80. Mckee, K.; Kerrylee, R.; Saintilan, N. Response of salt marsh and mangrove wetlands to changes in atmospheric response of salt marsh and mangrove wetlands to changes in atmospheric $\mathrm{CO}_{2}$, climate, and sea level. In Global Change and the Function and Distribution of Wetlands; Middleton, B., Ed.; Springer: Dordrecht, The Netherlands, 2012; pp. 63-96.

81. Cardona, P.; Botero, L. Soil characteristics and vegetation structure in a heavily deteriorated mangrove forest in the Caribbean Coast of Colombia. Biotropica 1998, 30, 24-34. [CrossRef]

82. Krauss, K.W.; Ball, M.C. On the halophytic nature of mangroves. Trees-Struct. Funct. 2013, $27,7-11$. [CrossRef]

83. Wang, W.; Yan, Z.; You, S.; Zhang, Y.; Chen, L.; Lin, G. Mangroves: Obligate or facultative halophytes? A review. Trees-Struct. Funct. 2011, 25, 953-963. [CrossRef]

84. Tovilla-Hernández, C.; Espino, G.; Orihuela-Belmonte, D. Impact of logging on a mangrove swamp in South Mexico: Cost/benefit. Rev. Biol. Trop. 2014, 49, 571-580.

85. Blanco, J.F.; Estrada, E.A.; Ortiz, L.F.; Urrego, L.E. Ecosystem-Wide Impacts of Deforestation in Mangroves: The Urabá Gulf (Colombian Caribbean) Case Study. ISRN Ecol. 2012, 2012, 958709. [CrossRef]

86. Walters, B.B. Ecological effects of small-scale cutting of Philippine mangrove forests. For. Ecol. Manage. 2005, 206, 331-348. [CrossRef]

87. Sippo, J.Z.; Lovelock, C.E.; Santos, I.R.; Sanders, C.J.; Maher, D.T. Mangrove mortality in a changing climate: An overview. Estuar. Coast. Shelf Sci. 2018, 215, 241-249. [CrossRef]

(C) 2020 by the authors. Licensee MDPI, Basel, Switzerland. This article is an open access article distributed under the terms and conditions of the Creative Commons Attribution (CC BY) license (http://creativecommons.org/licenses/by/4.0/). 